\title{
Carbon Footprint of Built Features and Planting Works during Construction, Maintenance and Renewal Stages at Urban Parks in Petaling Jaya, Selangor
}

\author{
Nurzuliza Jamirsah ${ }^{1 *}$, Ismail Said ${ }^{1}$, Badrulzaman Jaafar ${ }^{2}$ and Mohd Haniff \\ Mohd Hassani ${ }^{3}$ \\ ${ }^{1}$ Department of Landscape Architecture, Faculty of Built Environment and Surveying, Universiti Teknologi \\ Malaysia, 81310 UTM, Johor, Malaysia \\ ${ }^{2}$ Department of Landscape, Majlis Bandaraya Petaling Jaya, 46675 Petaling Jaya, Selangor, Malaysia \\ ${ }^{3}$ Department of Landscape, Khoo Soon Lee Realty Sdn Bhd, 41000 Klang, Selangor, Malaysia
}

\begin{abstract}
Carbon emissions in Malaysia are escalating due to rapid urbanisation wherein their sources are claimed to be generated by the construction industry, including urban park development. Upon completion of the urban park project, the vegetation will supposedly function immediately as a carbon sequester. However, the processes of building, maintaining, and renewing built features and plantings can emit additional carbon dioxide $\left(\mathrm{CO}_{2}\right)$ than the storage. Rigorous $\mathrm{CO}_{2}$ release across the maintenance and renewal stages may be contributed by park management activities, such as planting grooming, built feature rectification, and park maintenance works. This study investigated carbon footprint derived from built features and planting works during the construction, maintenance, and renewal stages of park management. Taman Bandaran Kelana Jaya and Taman Aman Petaling Jaya were chosen as the study sites as they were located at urban areas. Continued use of the parks resulted in a swift deterioration of its facilities, whereby this scenario would

ARTICLE INFO

Article history:

Received: 24 July 2020

Accepted: 07 October 2020

Published: 22 January 2021

DOI: https://doi.org/10.47836/pjst.29.1.22

E-mail addresses:

nurzulizajamirsah@gmail.com (Nurzuliza Jamirsah) ismailbinsaid@gmail.com (Ismail Said)

badrulzaman@mbpj.gov.my (Badrulzaman Jaafar)

mohdhaniff8731@gmail.com (Mohd Haniff Mohd Hassani)

* Corresponding author

ensure recurrent maintenance and renewal works were conducted for them. As-built drawings were utilised to identify the lists of inventories and work breakdown structure for every built feature and planting work to approximate the indirect $\mathrm{CO}_{2}$ emissions, which was aided by EToolLCD software. This study revealed that the amount of $\mathrm{CO}_{2}$
\end{abstract}


sequestered by the manicured vegetation was only $28.7 \%$ out of the total $\mathrm{CO}_{2}$ emission produced since its construction stage. Hence, urban parks can be perceived as a carbon source instead of a carbon sink medium.

Keywords: Carbon footprint, $\mathrm{CO}_{2}$ emission, $\mathrm{CO}_{2}$ sequestration, Project management life cycle, Urban parks

\section{INTRODUCTION}

The abundance of undesirable greenhouse gaseous remnants such as carbon dioxide $\left(\mathrm{CO}_{2}\right)$ is harmful to the climate. Malaysia's construction industry contributes $6 \%$ of $\mathrm{CO}_{2}$ to the atmosphere owing to its rapid development of construction activities (Begum, 2017). Meanwhile, urban parks are known for their purpose as a carbon sinker, whereby the provision of urban parks and greenery is perceived as the mitigating solution towards reducing the atmospheric carbon content. Prior studies (Almeida et al., 2018; Braun \& Bremer, 2019; Chen, 2015; Haq, 2011; Sun \& Chen, 2017) have found that urban parks alleviate $\mathrm{CO}_{2}$ emission within an urban setting, whereas their management procedures indirectly contribute to an additional release of atmospheric $\mathrm{CO}_{2}$. Furthermore, other studies including Connor et al. (2011), Feltynowski et al. (2017), Pocock (2009), and Strohbach et al. (2012), have discovered that they are the source of $\mathrm{CO}_{2}$ emission in urban areas, which originates from park management activities. Such activities include pruning, trimming, grass mowing, rubbish clearance, hardscape repairs, planting replacement, planting additions, planting treatment, soil treatment, watering, pest and disease control, weed control, and more.

Accordingly, the life cycle of urban park management consists of at least six stages, namely designing, construction, operation, maintenance, demolition, and renewal. These life cycle stages are allegedly contributing $\mathrm{CO}_{2}$ content to the atmosphere. According to Hisham et al. (2018), a notable amount of $\mathrm{CO}_{2}$ emissions is produced during the construction stage compared to the maintenance and operation stages. In particular, a significant oneoff amount of $\mathrm{CO}_{2}$ emitted is caused by the heavy use of machinery, transportation of materials, and labour. The stages, as mentioned earlier, often involve the use of machinery, especially during the early stage of project construction, and are associated with $\mathrm{CO}_{2}$ emission due to fuel consumption. Moreover, the types of materials used as landscape element construction can further influence the carbon footprint of the projects. Besides, the function of urban parks as a $\mathrm{CO}_{2}$ sink medium becomes null due to the $\mathrm{CO}_{2}$ emitted by their maintenance activities. Figure 1 shows the conceptual framework of this study, where the studied boundary is limited to the construction, maintenance, and renewal stages (Figure 1). Meanwhile, the stages of design, operation, and demolition are dismissed due to inconsistent data records and documentation. It is hypothesised that the management of urban parks is attributable to the significant $\mathrm{CO}_{2}$ liberation. Therefore, this study examines how much $\mathrm{CO}_{2}$ is produced from urban park management by dissecting its life cycle stages into a detailed work breakdown structure. 


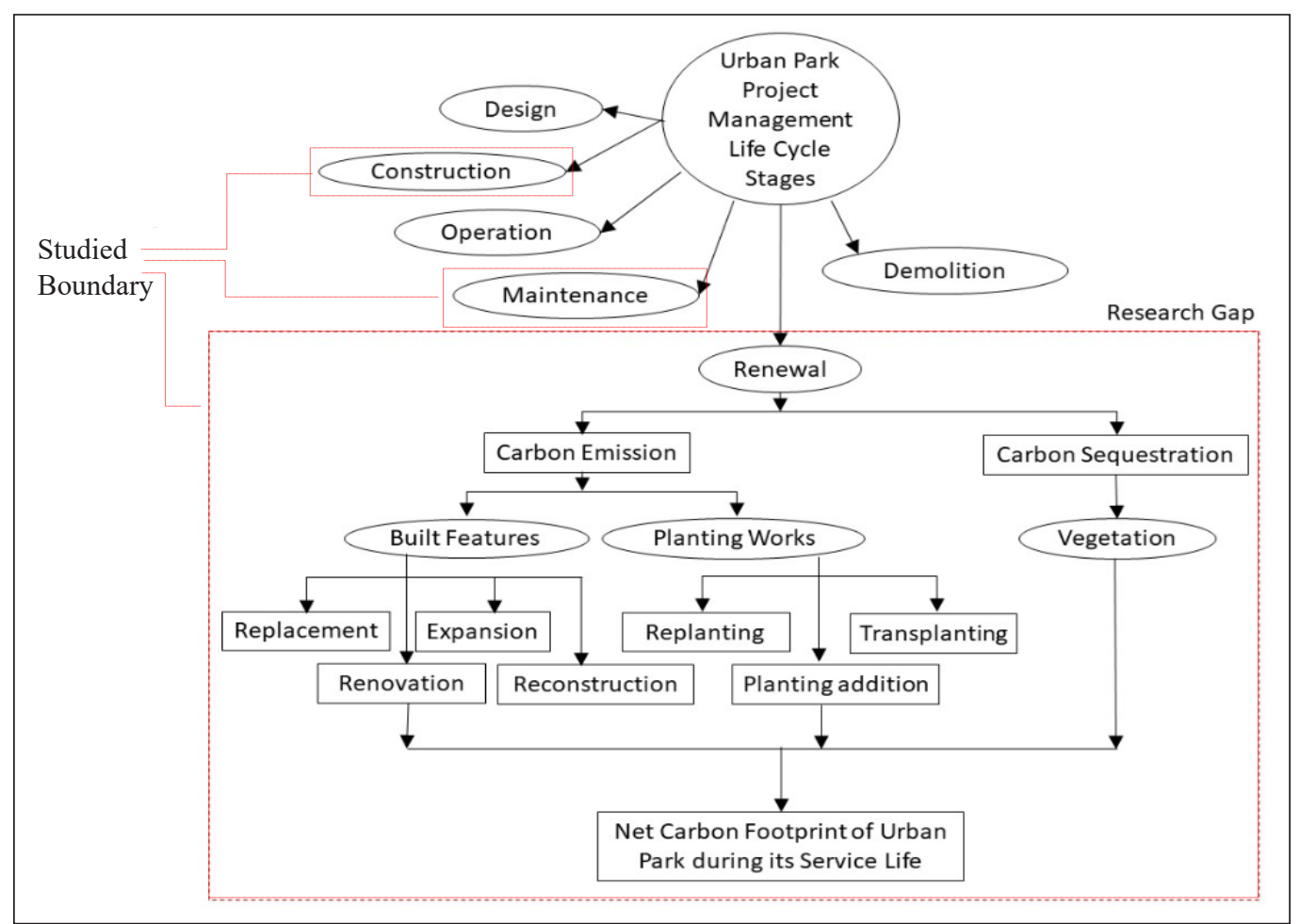

Figure 1. Urban park management carbon footprint conceptual framework

\section{MATERIAL AND METHODS}

Taman Bandaran Kelana Jaya (TBKJ) and Taman Aman Petaling Jaya (TAPJ) are located in the urban part of Selangor district and thus chosen as the study sites. Table 1 shows the sizes of the parks, which are $361,169 \mathrm{~m}^{2}$ and 80,339 $\mathrm{m}^{2}$, respectively. Both parks possess similar built features and planting composition ranging between $10.4 \%$ to $13.5 \%$ (built features) and $86.5 \%$ to $89.5 \%$ (plantings). Figure 2 shows that these parks are located adjacent to residential, institutional, and commercial areas, thereby indicating that they are utilised frequently as an open green space for urban dwellers. The study sites are chosen according to the following factors; a) urban parks are for public usage; b) as-built drawing availability; c) unmanned aerial vehicle (UAV) drone flight use is permitted.

Table 1

Urban parks background

\begin{tabular}{lll}
\hline Park Name & Taman Bandaran Kelana Jaya & Taman Aman Petaling Jaya \\
\hline Park Size, $\mathrm{m}^{2}$ & 361,169 & 80,339 \\
Park Age, year & 24 years old (1995-2019) & 18 years old (2001-2019) \\
Hardscape Composition & $10.4 \%$ & $13.5 \%$ \\
Softscape Composition & $89.6 \%$ & $86.5 \%$ \\
\hline
\end{tabular}




\section{As-built Drawings of Urban Parks}

Document retrieval of the old as-built drawings, construction drawings, and maintenance records was laborious. A representative of Petaling Jaya City Council (PJCC) acknowledged that they kept insufficient drawing documentation and records of preceding maintenance activities of the aged parks under their supervision. However, the parks being studied possessed sufficient as-built drawings to recognize the built features and planting inventories.

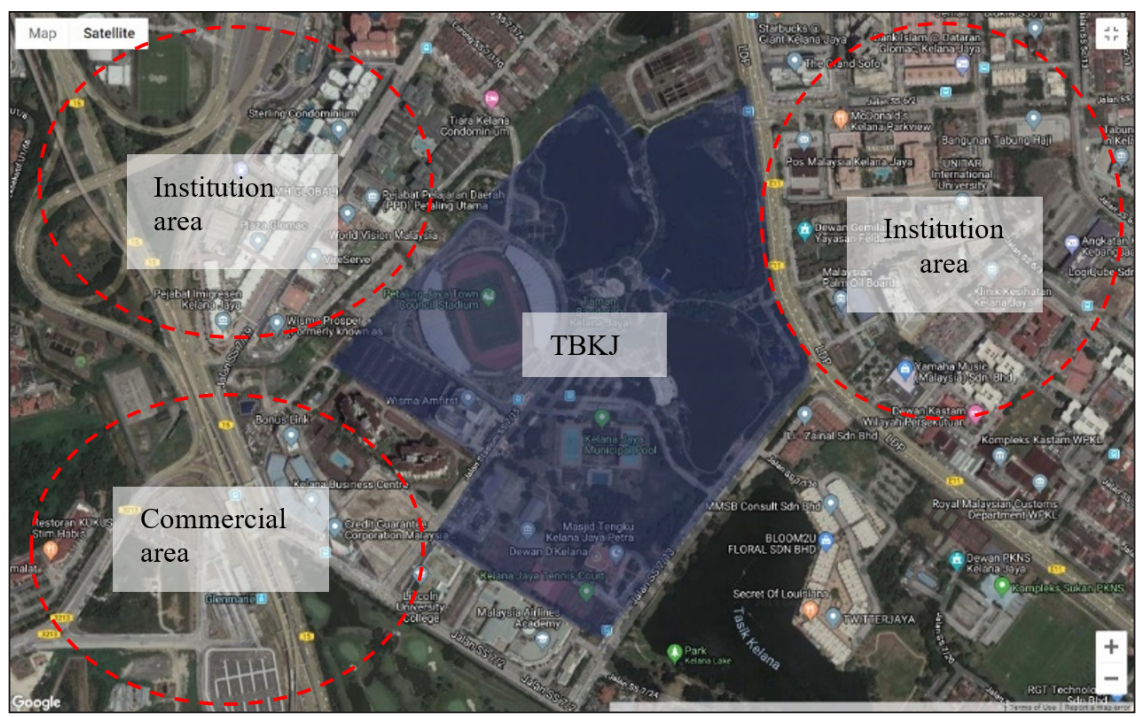

(a)

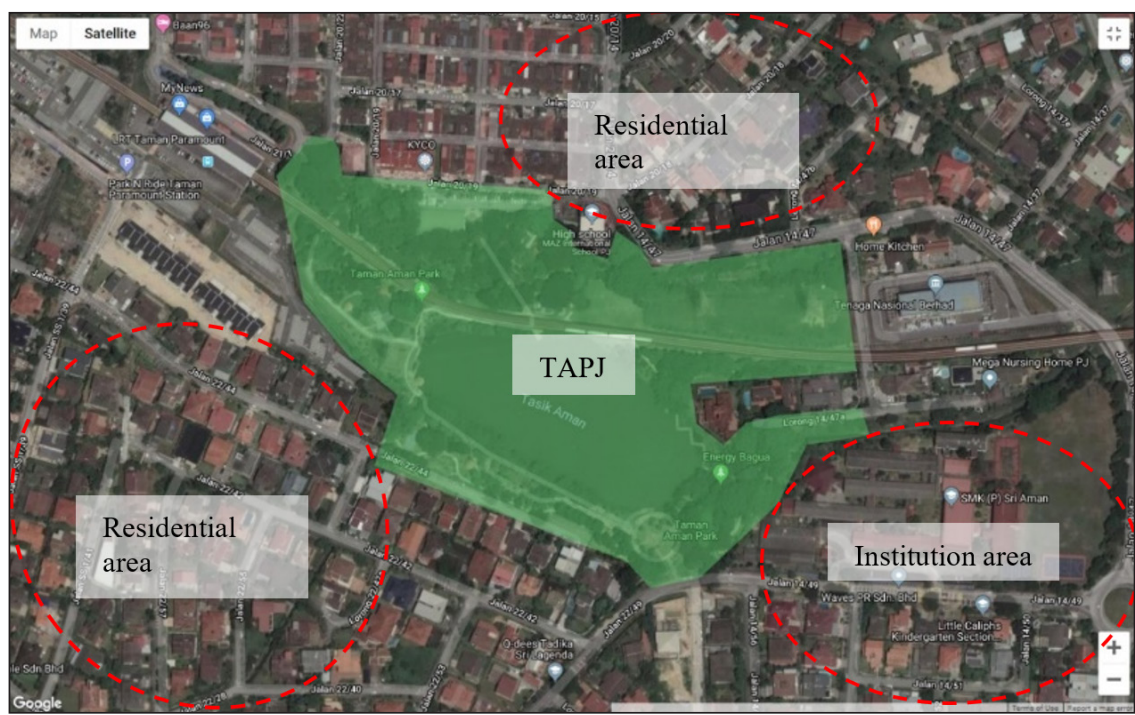

(b)

Figure 2. Site context of: (a) TBKJ; and (b) TAPJ 


\section{Work Breakdown Structure and Park Management Life Cycle}

Every urban park is composed of built features and planting components. By referring to the as-built drawings, Table 2 shows the component inventory during the construction stage, which is fragmented to small-scale components, otherwise known as the work breakdown structure (WBS). The WBS was employed to predict the $\mathrm{CO}_{2}$ content released by each urban park. Based on the construction $\mathrm{CO}_{2}$ emission, this study predicted the $\mathrm{CO}_{2}$ emissions for the maintenance and renewal stages accordingly. The renewal stage can be divided into two categories, namely built feature renewals and planting renewals.

Table 2

Work breakdown structure for several built features during construction stage of the studied urban parks

\begin{tabular}{|c|c|c|}
\hline $\begin{array}{l}\text { Built } \\
\text { Features }\end{array}$ & $\begin{array}{l}\text { Work Breakdown } \\
\text { Structure }\end{array}$ & Work Packages (eToolLCD) \\
\hline \multirow[t]{12}{*}{ Toilet } & Site preparation & Small scale excavation \\
\hline & Foundation & Formwork (Foundations) \\
\hline & Services & Plumbing-100mm Insulated Pipework (22mm dia) \\
\hline & & Multi-Res Bedroom LED Lighting \\
\hline & Floor & Concrete Floor, $125 \mathrm{~mm}$ slab. $40 \mathrm{MPa} .4 \%$ reo by volume \\
\hline & Column & Concrete column structural, $30 \mathrm{Mpa} 3 \%$ reo by volume \\
\hline & Wall & Concrete Walls ( $450 \mathrm{~mm}, 40 \mathrm{MPa}, 25 \% \mathrm{BFS}, 2 \%$ reo by volume) \\
\hline & & Partition wall hard resin \\
\hline & Roof & Roof - TimberTruss/ClayTile $/ 25^{\circ} \mathrm{Pitch}$ \\
\hline & Door & Internal Door - HollowCoreTimber/WoodenJam/painted (m2) \\
\hline & Finishes & External Finish - Paint(SuperStructure) \\
\hline & & Internal Finish - Paint (standard) \\
\hline \multirow{4}{*}{$\begin{array}{l}\text { Concrete } \\
\text { Seating }\end{array}$} & Foundation & Crushed Rock infill \& compaction \\
\hline & Floor & Concrete Floor, $100 \mathrm{~mm}$ slab. $25 \mathrm{MPa} .3 .8 \%$ reo by volume \\
\hline & Wall & Assembly only pour concrete \\
\hline & Finishes & External Wall Finish - 10mm Render (clay) \\
\hline \multirow{6}{*}{$\begin{array}{l}\text { Shelter } \\
\text { (Gazebo) }\end{array}$} & Site preparation & Small scale excavation \\
\hline & Foundation & Formwork (Foundations) \\
\hline & Floor & Concrete Floor, $125 \mathrm{~mm}$ slab. $40 \mathrm{MPa} .4 \%$ reo by volume \\
\hline & Column & Concrete column structural, 30Mpa 3\% reo by volume \\
\hline & Roof & Roof - TimberTruss/ClayTile $/ 25^{\circ} \mathrm{Pitch}$ \\
\hline & Finishes & External Finish - Paint (SuperStructure) \\
\hline \multirow[t]{5}{*}{ Bridge } & Site preparation & Small scale excavation \\
\hline & Foundation & Formwork (Foundations) \\
\hline & Floor & Bridge Deck Precast concrete \\
\hline & Handrail & Steel handrail $50 \mathrm{~mm}$ diam \\
\hline & Finishes & Floor Finish - Coloured Epoxy Concrete Floor Coating \\
\hline \multirow{2}{*}{$\begin{array}{l}\text { Playground } \\
\text { floor }\end{array}$} & Site preparation & Small scale excavation \\
\hline & Foundation & Formwork (Foundations) \\
\hline
\end{tabular}


Table 2 (continue)

\begin{tabular}{|c|c|c|}
\hline $\begin{array}{l}\text { Built } \\
\text { Features }\end{array}$ & $\begin{array}{l}\text { Work Breakdown } \\
\text { Structure }\end{array}$ & Work Packages (eToolLCD) \\
\hline \multirow[t]{2}{*}{$\begin{array}{l}\text { Playground } \\
\text { floor }\end{array}$} & Floor & $\begin{array}{l}\text { Concrete Floor - } 100 \mathrm{~mm} \text { slab on ground } / 30 \mathrm{MPa} / 1 \% \text { reo by } \\
\text { volume } / \text { no fd }\end{array}$ \\
\hline & Finishes & Landscaping - Rubber Play Ground Surface \\
\hline \multirow{4}{*}{$\begin{array}{l}\text { Parcourse } \\
\text { floor }\end{array}$} & Site preparation & Small scale excavation \\
\hline & Foundation & Formwork (Foundations) \\
\hline & Floor & $\begin{array}{l}\text { Concrete Floor - } 100 \mathrm{~mm} \text { slab on ground } / 30 \mathrm{MPa} / 1 \% \text { reo by } \\
\text { volume } / \text { no fd }\end{array}$ \\
\hline & Finishes & Landscaping - Rubber Play Ground Surface \\
\hline \multirow[t]{4}{*}{ Plaza } & Site preparation & Small scale excavation \\
\hline & Foundation & Formwork (Foundations) \\
\hline & Floor & $\begin{array}{l}\text { Concrete Floor - } 100 \mathrm{~mm} \text { slab on ground } / 30 \mathrm{MPa} / 1 \% \text { reo by } \\
\text { volume/no fd }\end{array}$ \\
\hline & Finishes & Floor Finish - Coloured Epoxy Concrete Floor Coating \\
\hline \multirow[t]{4}{*}{ Walkway } & Site preparation & Small scale excavation \\
\hline & Foundation & Formwork (Foundations) \\
\hline & Floor & $\begin{array}{l}\text { Concrete Floor - } 100 \mathrm{~mm} \text { slab on ground } / 30 \mathrm{MPa} / 1 \% \text { reo by } \\
\text { volume/no fd }\end{array}$ \\
\hline & Finishes & Floor Finish - Coloured Epoxy Concrete Floor Coating \\
\hline Lake & Site preparation & Bulk earthworks - cut (used on site) \\
\hline \multirow{2}{*}{$\begin{array}{l}\text { Parking } \\
\text { area }\end{array}$} & Site preparation & Large Scale Excavation Sand infill \\
\hline & Floor & Paving/Road - Asphalt $80 \mathrm{~mm}$ on $300 \mathrm{~mm}$ aggregate base \\
\hline \multirow{2}{*}{$\begin{array}{l}\text { Pole } \\
\text { Lighting }\end{array}$} & Foundation & Crushed Rock infill \& compaction \\
\hline & Lighting & Lighting, $70 \mathrm{~W}$ pedestrian area lighting on $4 \mathrm{~m}$ pole, installed \\
\hline
\end{tabular}

* Work packages were derived from eToolLCD Software at www.etoollcd.com

Table 3 shows built feature renewal, which consists of four sub-stages, specifically replacement, renovation, expansion, and reconstruction. Meanwhile, Table 4 shows that the planting renewal category consists of three sub-stages, which are replanting, planting additions, and transplanting. Altogether, these seven renewal sub-stages were ranked based on the intensity of work: the amount of work performed by a team of workers divided by unit time (Kabanov, 2018).

A set of definition is justified to avoid an inconsistent understanding of the park management terminologies, construction, maintenance, and renewal. Firstly, construction in project management describes the act of erecting a large structure after which its completion is called a project. Examples of construction works include foundation excavation, flooring, column erection, beam fastening, roof works, and finishes. Regardless, the construction $\mathrm{CO}_{2}$ emission is typically a one-off value and occurs once only throughout the entire urban park life cycle. 
Table 3

Work breakdown structure for a shelter from the construction, maintenance and renewal stages

\begin{tabular}{|c|c|c|c|c|c|c|}
\hline \multirow{2}{*}{$\begin{array}{l}\text { Example } \\
\text { of Built } \\
\text { Feature }\end{array}$} & \multirow{2}{*}{$\begin{array}{c}\text { Construction } \\
\text { WBS }\end{array}$} & \multirow{2}{*}{$\begin{array}{c}\text { Maintenance } \\
\text { WBS }\end{array}$} & \multicolumn{4}{|c|}{ Renewal WBS } \\
\hline & & & $\begin{array}{c}\text { Replacement } \\
\text { WBS }\end{array}$ & $\begin{array}{c}\text { Renovation } \\
\text { WBS }\end{array}$ & $\begin{array}{c}\text { Expansion } \\
\text { WBS }\end{array}$ & $\begin{array}{c}\text { Reconstruction } \\
\text { WBS } \\
\end{array}$ \\
\hline \multirow{7}{*}{ Shelter } & Site preparation & & \multirow{6}{*}{ Removal } & \multirow[b]{2}{*}{ Demolition } & \multirow{3}{*}{ Foundation } & Demolition \\
\hline & Foundation & & & & & $\begin{array}{l}\text { Site } \\
\text { preparation }\end{array}$ \\
\hline & & Finishes & & \multirow{4}{*}{ Roof } & & Foundation \\
\hline & Floor & FIIISHES & & & Floor & Floor \\
\hline & Column & & & & Column & Column \\
\hline & Roof & & & & Roof & Roof \\
\hline & Finishes & & Roof & Finishes & Finishes & Finishes \\
\hline
\end{tabular}

Table 4

Work breakdown structure for trees from the planting installation, planting maintenance and renewal stages

\begin{tabular}{|c|c|c|c|c|c|}
\hline \multirow{2}{*}{$\begin{array}{l}\text { Example of } \\
\text { Planting Work }\end{array}$} & \multirow{2}{*}{$\begin{array}{c}\text { Planting } \\
\text { Installation } \\
\text { WBS }\end{array}$} & \multirow{2}{*}{$\begin{array}{c}\text { Planting } \\
\text { Maintenance } \\
\text { WBS }\end{array}$} & \multicolumn{3}{|c|}{ Renewal WBS } \\
\hline & & & $\begin{array}{c}\text { Replanting } \\
\text { WBS }\end{array}$ & $\begin{array}{c}\text { Planting } \\
\text { addition WBS }\end{array}$ & $\begin{array}{c}\text { Transplanting } \\
\text { WBS }\end{array}$ \\
\hline \multirow[t]{2}{*}{ Tree } & $\begin{array}{l}\text { Site } \\
\text { preparation }\end{array}$ & \multirow{2}{*}{$\begin{array}{l}\text { Pruning/ } \\
\text { Fertilizer/ Pest } \\
\text { control }\end{array}$} & $\begin{array}{l}\text { Site } \\
\text { preparation }\end{array}$ & Site preparation & $\begin{array}{l}\text { Site } \\
\text { preparation }\end{array}$ \\
\hline & Planting & & Planting & Planting & Planting \\
\hline
\end{tabular}

Next, maintenance entails the preservation of a project or the facilities in the project to its original state post-completion to avoid decomposition. Examples of maintenance works are repainting jobs on built structures, park up-keeping, debris clearance, tree pruning, fertilising, and irrigation. It usually occurs monthly for plantings and yearly for built features.

Finally, renewal is defined as the act to renew a design when it fails to meet the expectation of the users. Examples of renewal works are revamping the existing built structures, park size extension, replanting perished or frail plantings, transplanting, and replanting softscapes according to the upgraded urban park design. This study found that renewal consisted of seven significant sub-stages, namely replacement, replanting, expansion, planting addition, renovation, reconstruction, and transplanting.

Moreover, replacement refers to solely replacing any damaged and defected items, such as timber material, door, roof, playmat, and more. Meanwhile, replanting can be described as solely replanting dead trees by using the number of dead trees $(1.4 \%$ mortality rate) out of total tree numbers of the park. Next, renovation refers to only renovating any decayed or damaged structures once every five years. This ' 5 -year' period is acknowledged by the experts who had experienced in handling park management (PJCC and KSL 
representatives). Expansion is defined by expanding the park with the assumption of urban park components numbers added were based on the park halved amount of total previous constructed item. Planting addition refers to the number of trees added halved the total numbers of trees previously planted. Reconstruction refers to the items reconstructed in the park to equal the amount of previously constructed items in total. At a minimum of every ten years, the urban park designs are usually revamped to achieve a fresher environment. Based on Google Earth satellite images of the studied parks, changes of park morphology had been detected by comparing satellite images from parks completion year until the year 2019. Thus far, several renewal works have been done. Next, transplanting refers to the works of moving healthy or heritage trees within or outside of the urban park. The number of transplanted trees can be calculated using $1.4 \%$ of the tree mortality numbers to be replanted on the park.

Following this, patterns of $\mathrm{CO}_{2}$ liberation during the construction stage emerged, and the WBS pattern was extrapolated during the maintenance and renewal stages for predicting the $\mathrm{CO}_{2}$ emission in the context of other urban parks with similar microclimate, built features, plant species, and management life cycles.

\section{Built Features Inventory}

The built feature is any built form or structure in an urban park categorised as free-standing elements, horizontal and vertical surfaces ( Hisham et al., 2018; Connor et al., 2011). $\mathrm{CO}_{2}$ release estimation of these built features for TBKJ and TAPJ was done using EToolLCD Software, an online paid software that aids in calculating the WBS for construction items, including foundation, column, wall, roof, and finishes (Eslamirad \& Mahdavinejad, 2018; De Wolf et al., 2017). The floor areas in square metre $\left(\mathrm{m}^{2}\right)$ of each built feature were gathered from the as-built drawings. Height, length and width dimensions were collected using an unmanned aerial vehicle (UAV) drone flights over the parks using the decided transect paths (Figure 3a and 3b). The output of the UAV flights is orthophotos. This method is termed as Structure from Motion (SfM), where a series of two dimensional (2D) orthophotos is utilised to reconstruct the three dimensional (3D) model of a built object. The $3 \mathrm{D}$ models of the urban parks generated by MeshLab Software were used to measure the verifiable height, length and width in metre $(\mathrm{m})$. The model is reliable as it is an accurate representation of the Earth's surface. These new techniques are practical for data collection at places that are difficult to reach, such as lush vegetation in urban parks (Shashi \& Jain, 2007). A DJI Phantom 4 Pro drone was used to capture low-altitude photographs, and GPS devices were used to survey the reference points (Ground Control Points) (Figure 3c). These data were processed in an SfM workflow to create elevation point cloud to derive orthophotos and canopy height models (CHM). Thus, UAV flights data collection is reliable coequal with LiDAR but at an inexpensive cost (Ngadiman et al., 2018). 


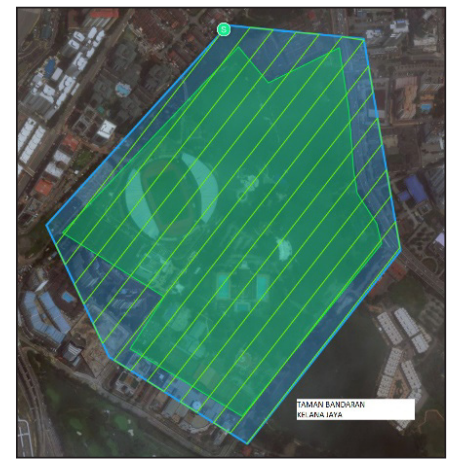

(a)

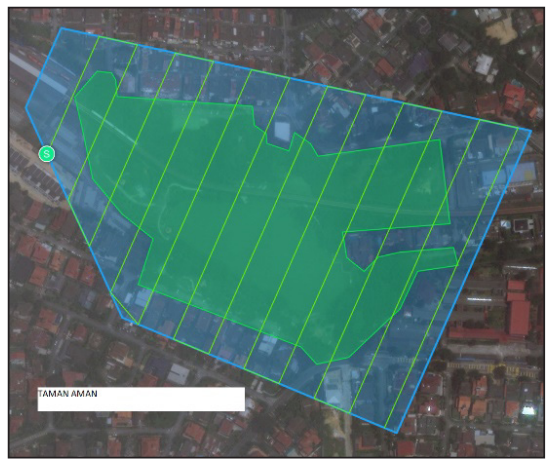

(b)

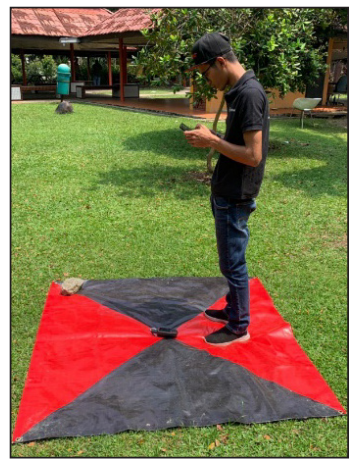

(c)

Figure 3. (a) TBKJ UAV drone transect path; (b) TAPJ UAV drone transect path; and (c) Ground Control Point coordinate tagging

\section{Planting Inventory}

Planting is any vegetation prescribed during the design stage of an urban park, such as trees, ornamental flowers, edible plants, shrubs, groundcovers and turfs (Hisham et al., 2018). The tree numbers and species were accumulated from the as-built drawings. Tree heights and diameter at breast heights (DBH) were collected from the UAV flights and onsite measurements, respectively. The output of UAV flights was a Canopy Height Model (CHM) in which the average tree heights could be identified (Figure 4a and 4b). These urban parks have been in existence for 24 years (TBKJ) and 18 years (TAPJ) each, thereby both having matured vegetation with an average overall height of $15.6 \mathrm{~m}$ (Figure 4a) and $17.8 \mathrm{~m}$ (Figure $4 \mathrm{~b}$ ), respectively. Planting types observed were trees and turfs exclusively due to shrubs being frequently altered at the parks, and the records for any altered species and numbers altered were unavailable. Plantings $\mathrm{CO}_{2}$ emission were calculated from the commencement of planting activities on-site until the growing process such as pruning, fertilising and weeding presently.

Trees were categorised into three; small $(<9 \mathrm{~m})$, medium $(\leq 9$ to $21 \mathrm{~m} \geq)$ and large $(>$ $21 \mathrm{~m}$ ) (Arbor Day Foundation, 2020). $\mathrm{CO}_{2}$ sequestrations were calculated based on the $\mathrm{DBH}$, height, numbers and years of the trees planted on the urban parks 1348 trees at TBKJ and 551 trees at TAPJ. Table 5 shows the formulae to estimate $\mathrm{CO}_{2}$ sequestration by trees and turfs developed by Othman and Kasim (2016). Tree mortality rates depend on the year and type of microclimate where the vegetation is planted. In a tropical climate such as Malaysia, the value is low in the case of temperatures between 26.0 and $29.5{ }^{\circ} \mathrm{C}$. This study adopted $1.40 \%$ tree mortality rate at a tropical climate out of total tree numbers at each urban park, which was as suggested by previous studies (Aleixo et al., 2019; Arellano et al., 2019; King et al., 2006).

Turf is commonly found in large areas of natural and agricultural lands. Due to urbanisation, such green spaces have been replaced with golf courses, public parks, private 
lawns, and sports fields (Alig et al., 2004). Five urban parks were observed between the year 2018-2019, and only two parks were presented in this paper. Based on the observation conducted onto these parks, turf height must be kept at an optimum level of approximately $2.5 \mathrm{~cm}$ to $4.0 \mathrm{~cm}$ represented as $x$ in figure 6a (Marcum, 2010).

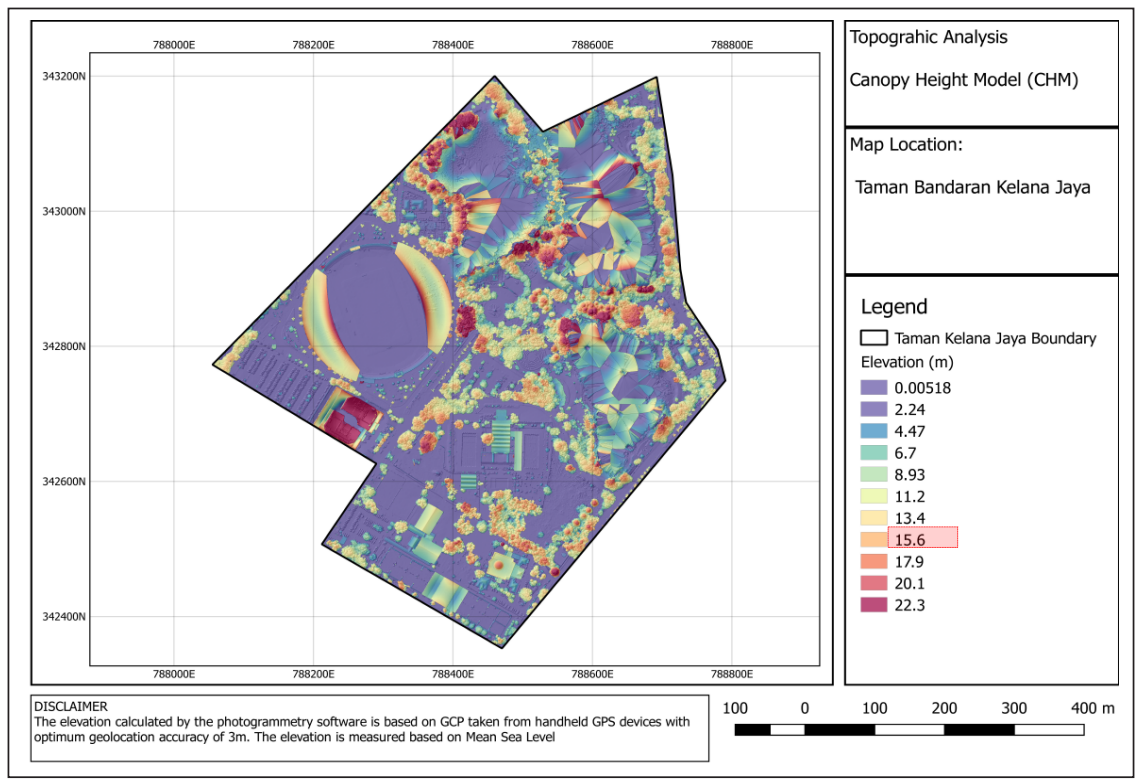

(a)

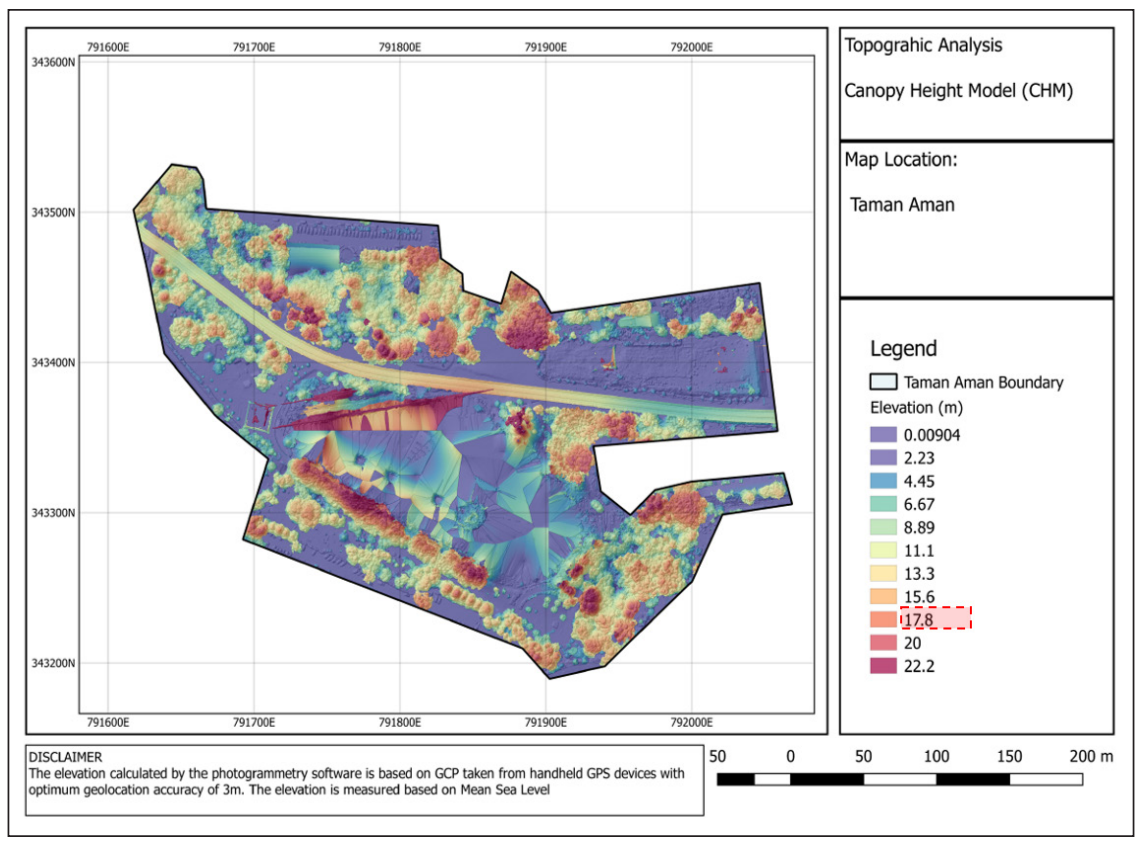

(b)

Figure 4. (a) CHM of TBKJ; and (b) CHM of TAPJ 
Figure 5a shows the turf specimen height was measured as $4.95 \mathrm{~cm}$. After two to three weeks, the turf reached approximately $7.5 \mathrm{~cm}$ to $12.0 \mathrm{~cm}$ tall represented as $3 x$ shown in Figure 6b. Turf exceeding $12.0 \mathrm{~cm}$ were cut and unfavourable due to pest infestation. At the optimum height, they can germinate seeds and retain moisture longer within the topsoil. At the same time, excessively short turf leads to inefficient photosynthesis, stressed root system, and is vulnerable for pathogen infestation. Thus, mowing was carried out every three weeks onto the turf at these parks.

Figure $5 b$ shows the length of the grass cut was $1 / 3$ of total grass height which was 4.03 $\mathrm{cm}$. This cut height is equivalent to the $x$ grass height of $2.5 \mathrm{~cm}$ to $4.0 \mathrm{~cm}$ delivered from nursery and previously planted on site (Figure 6a). The carbon emissions from mowing were estimated based on the number of cumulative annual mowing events (Braun \& Bremer, 2019). This study applied 17 times of mowing events minimum required annually. Hence,

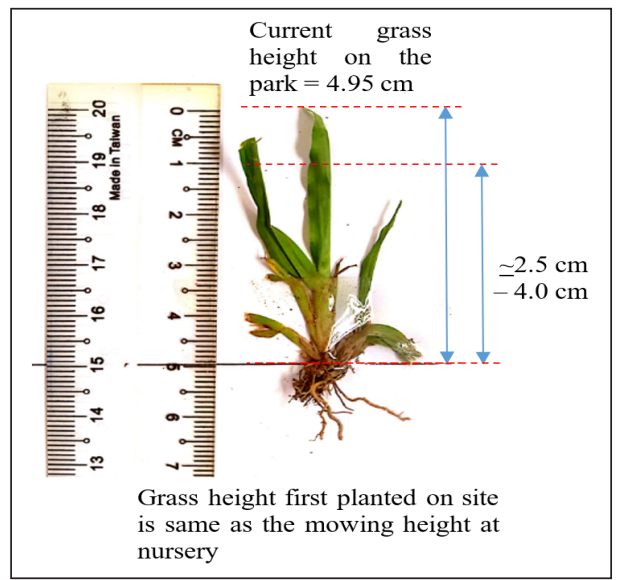

(a)

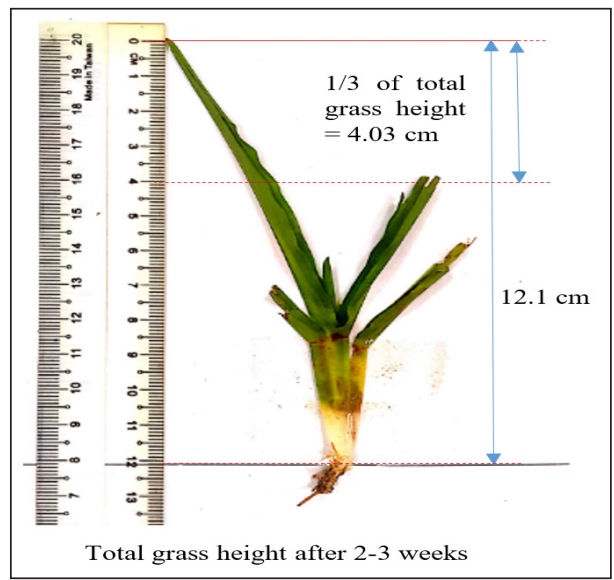

(b)

Figure 5. (a) Turf specimen of the park post mowing $=4.95 \mathrm{~cm}$; and (b) length of grass blade clipped at $1 / 3$ of total turf height represent the turf height first planted on site

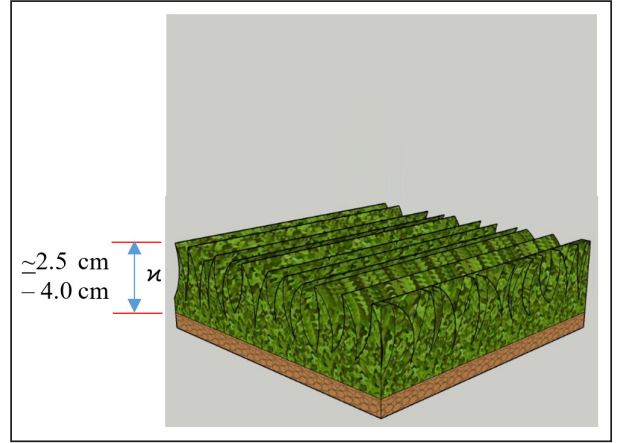

(a)

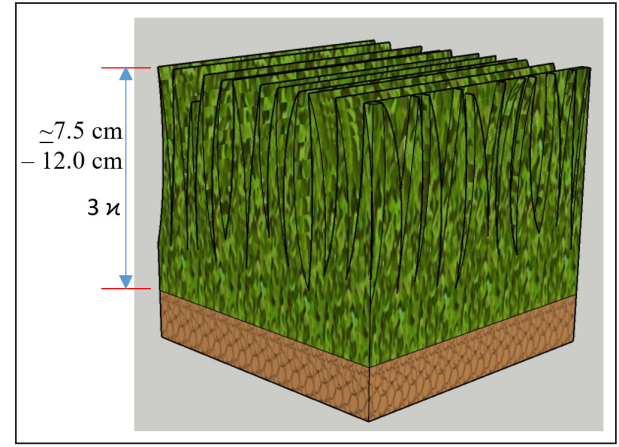

(b)

Figure 6. a) $\boldsymbol{x}$ is turf mowing height at $2.5 \mathrm{~cm}$ to $4.0 \mathrm{~cm}$ (Marcum, 2010); and b) $3 \boldsymbol{u}$ is turf height after 2 to 3 weeks at $7.5 \mathrm{~cm}$ to $12.0 \mathrm{~cm}$ 
Table 5

$\mathrm{CO}_{2}$ sequestration formula for trees and turf

\begin{tabular}{|c|c|}
\hline $\mathrm{CO}_{2}$ Sequestration Rate formula for Trees & $\mathrm{CO}_{2}$ Sequestration Rate formula for Turf \\
\hline $\begin{array}{l}\text { Total Green Weight, TGW }(\mathrm{D}=<11 \text { in }), \mathrm{W}=0.25 \mathrm{D}^{2} \mathrm{H} \\
(1.2)\end{array}$ & $\begin{array}{l}\text { Total Dry Weight, TDW }=0.56 \mathrm{x} \text { area in } \mathrm{m}^{2} \\
\text { Total Carbon Weight. TCW }=\text { TDW } \times 0.427\end{array}$ \\
\hline $\begin{array}{l}\text { Total Green Weight, TGW }(\mathrm{D}=>11 \text { in }), W=0.15 \mathrm{D}^{2} \mathrm{H} \\
(1.2)\end{array}$ & $\begin{array}{l}\text { Total } \mathrm{CO}_{2} \text { Weight, } \mathrm{TCO}_{2} \mathrm{~W}=\mathrm{TCW} \times 3.6663 \\
\text { Exp } 1-\mathrm{TCO}_{2} \mathrm{~W} \text { to date }=\end{array}$ \\
\hline $\begin{array}{l}\text { Total Dry Weight, } \mathrm{TDW}=\mathrm{TGW} \times 0.725 \\
\text { Total Carbon Weight, } \mathrm{TCW}=\mathrm{TDW} \times 0.5 \\
\text { Total } \mathrm{CO}_{2} \text { Weight, } \mathrm{TCO}_{2} \mathrm{~W}=\mathrm{TCW} \times 3.6663 \\
\mathrm{TCO}_{2} \mathrm{~W} \text { to date }=\mathrm{TCO}_{2} \mathrm{~W} \times * * 1.4 \% \text { x Tree nos }\end{array}$ & $\begin{array}{l}\mathrm{TCO}_{2} \mathrm{~W} \text { x } 17 \text { x park age } \mathrm{x} * * * 0.44 \text { grass mortality } \\
\text { rate }\end{array}$ \\
\hline
\end{tabular}

* adaptation of Othman and Kasim (2016) trees and turf sequestration

** tree mortality rate adopted from Aleixo et al. (2019)

*** grass mortality rate adopted from Lauenroth and Adler (2008)

this study adopted the formula for turf $\mathrm{CO}_{2}$ sequestration developed by Othman and Kasim (2016) with further multiplication of 17 times mowing events, park age and $0.44 \%$ grass mortality rate as expression 1 shown in Table 5.

\section{RESULTS AND DISCUSSION}

\section{Built Features Inventory}

According to Petaling Jaya City Council and KSL representatives, an urban park may have undergone replacement, replanting, renovation, expansion, planting addition, reconstruction, and transplanting at least once throughout its service life span. Carbon emission for TBKJ (24 years) and TAPJ (18 years) were estimated as 95,325,744 $\mathrm{kgCO}_{2} \mathrm{eq}$ and $29,152,303 \mathrm{kgCO}_{2}$ eq respectively.

$\mathrm{CO}_{2}$ emission for the construction stage is estimated as a one-off emission. Maintenance stage emission was calculated from the park cleaning, and make-good works multiplied with park age. Built feature renewal emission consisted of four substages, namely replacement, renovation, expansion and reconstruction. The $\mathrm{CO}_{2}$ emission of replacement works was considering the repairing work such as scrapping damaged playground mat and change it to a similar mat. The emission for renovation works, including changing the existing built feature to a different shape, material and finishes. The emission for expansion works, including the enlargement of park surface areas and addition of built features quantity. The emission of reconstruction works is focusing on revamping the whole park design with a refreshed design suitable for current urban users. This study assumed that the reconstructed design followed the previous design, material, finishes and quantities.

The built features produced a total of $38,850,190 \mathrm{kgCO}_{2}$ eq (Table 6) and 8,330,614 $\mathrm{kgCO}_{2}$ eq (Table 7) of $\mathrm{CO}_{2}$ emissions during the construction stage of the urban parks. The highest $\mathrm{CO}_{2}$ emission identified was produced by site preparation including earthworks 
Table 6

Built feature inventories and $\mathrm{CO}_{2}$ emission estimation for TBKJ during construction, maintenance and renewal stages

\begin{tabular}{|c|c|c|c|c|c|c|}
\hline \multirow[b]{3}{*}{ Built Feature } & \multirow[b]{3}{*}{$\begin{array}{l}\text { Construction } \\
\text { Stage }\end{array}$} & \multicolumn{5}{|c|}{ Carbon Emissions for Built Feature at TBKJ } \\
\hline & & \multirow{2}{*}{$\begin{array}{l}\text { Maintenance } \\
\text { Stage ( } 24 \\
\text { years) }\end{array}$} & \multicolumn{4}{|c|}{ Renewal Stage } \\
\hline & & & $\begin{array}{l}\text { Replacement } \\
\text { Stage }\end{array}$ & $\begin{array}{l}\text { Renovation } \\
\text { Stage }\end{array}$ & $\begin{array}{l}\text { Expansion } \\
\text { Stage }\end{array}$ & $\begin{array}{l}\text { Reconstruction } \\
\text { Stage }\end{array}$ \\
\hline $\begin{array}{l}\text { Site } \\
\text { Preparation/ } \\
\text { Overall works }\end{array}$ & $32,279,571$ & 39,591 & 15,430 & 21,216 & 383,251 & $32,500,099$ \\
\hline Toilet & 32,195 & 908 & 1,939 & 13,889 & 16,396 & 32,657 \\
\hline $\begin{array}{l}\text { Concrete } \\
\text { seating }\end{array}$ & 6,572 & 1,325 & 19 & - & 3.339 & 6,572 \\
\hline Planter box & 6,324 & 1,111 & - & - & 3,162 & 6,325 \\
\hline $\begin{array}{l}\text { Concrete } \\
\text { structure }\end{array}$ & 115,696 & 8,456 & 50,154 & 57,076 & 35,014 & 115,695 \\
\hline Shelter & 24,671 & 809 & 10,149 & 10,958 & 11,693 & 23,604 \\
\hline Pergola & 24,745 & 1,578 & 12,157 & 20,144 & 12,375 & 24,750 \\
\hline Bridge & 6,938 & 381 & 282 & - & 3,406 & 6,938 \\
\hline $\begin{array}{l}\text { Playground / } \\
\text { Play court }\end{array}$ & 222,529 & 187,920 & 20,782 & 189,081 & 110,864 & 222,889 \\
\hline Parcourse & 11,620 & 10,281 & 1,083 & 10,302 & 5,846 & 11,620 \\
\hline Plaza & 270,456 & 58,915 & - & - & 131,714 & 270,456 \\
\hline Walkway & 447,855 & 124,450 & 256,521 & - & 221,398 & 447,855 \\
\hline Parking area & $1,619,422$ & - & - & - & 809,711 & $1,619,422$ \\
\hline Lighting & $2,594,673$ & - & $2,591,113$ & - & $1,295,696$ & $2,591,113$ \\
\hline $\begin{array}{l}\text { Man-Made } \\
\text { Lake }\end{array}$ & $1,186,923$ & - & - & - & 593,461 & $1,186,923$ \\
\hline Total & $38,850,190$ & 435,724 & $2,964,691$ & 322,667 & $3,660,343$ & $39,070,477$ \\
\hline Overall Built & $38,850,190$ & $10,457,376$ & $2,964,691$ & 322,667 & $3,660,343$ & $39,070,477$ \\
\hline $\begin{array}{l}\text { Feature } \\
\text { Carbon } \\
\text { Emission, } \\
\mathrm{kgCO}_{2} \mathrm{eq}\end{array}$ & \multicolumn{6}{|c|}{$95,325,744$} \\
\hline
\end{tabular}

* $\mathrm{CO}_{2}$ emission estimations were done using eToolLCD Software at www.etoollcd.com

excavation and movements, drainage ditching system and electrical cabling placement, with $32,279,571 \mathrm{kgCO}_{2}$ eq and 7,180,299 $\mathrm{kgCO}_{2}$ eq, respectively. This emission is due to the high number of heavy machinery involved in the works. This was followed by lighting (TBKJ) and man-man lake (TAPJ) at 2,594,673 $\mathrm{kgCO}_{2}$ eq and 280,792 $\mathrm{kgCO}_{2}$ eq, respectively. Lighting $\mathrm{CO}_{2}$ emission was the highest value due to 400 pedestrian lighting fixtures allocated at the TBKJ. Their energy usage during the operation phase assumed that the 70W/bulb was running for 12 hours ( 7 pm till $7 \mathrm{am}$ ) daily. Similarly, the man-made lake produced the highest $\mathrm{CO}_{2}$ emission at TAPJ due to heavy machinery used during the 
Table 7

Built feature inventories and $\mathrm{CO}_{2}$ emission estimation for TAPJ during construction, maintenance and renewal stages

\begin{tabular}{|c|c|c|c|c|c|c|}
\hline \multicolumn{7}{|c|}{ Carbon Emissions for Built Feature at TAPJ } \\
\hline \multirow[b]{2}{*}{ Built Feature } & \multirow{2}{*}{$\begin{array}{l}\text { Construction } \\
\text { Stage }\end{array}$} & \multirow{2}{*}{$\begin{array}{l}\text { Maintenance } \\
\text { Stage (18 } \\
\text { years) }\end{array}$} & \multicolumn{4}{|c|}{ Renewal Stage } \\
\hline & & & $\begin{array}{l}\text { Replacement } \\
\text { Stage }\end{array}$ & $\begin{array}{l}\text { Renovation } \\
\text { Stage }\end{array}$ & $\begin{array}{l}\text { Expansion } \\
\text { Stage }\end{array}$ & $\begin{array}{l}\text { Reconstruction } \\
\text { Stage }\end{array}$ \\
\hline Site & & & & & & \\
\hline $\begin{array}{l}\text { Preparation/ } \\
\text { Overall } \\
\text { works }\end{array}$ & $7,180,299$ & 11,489 & 8,850 & 4,768 & 85,639 & $7,254,583$ \\
\hline Toilet & 8,761 & 446 & 1,603 & 4,441 & 5,289 & 8,763 \\
\hline $\begin{array}{l}\text { Concrete } \\
\text { seating }\end{array}$ & 3,130 & 114 & 19 & - & 1,539 & 3,130 \\
\hline Shelter & 19,262 & 707 & 8,529 & 9,236 & 9,589 & 16,315 \\
\hline Bridge & 16,726 & 3,137 & 11,819 & - & 27,027 & 16,727 \\
\hline $\begin{array}{l}\text { Playground / } \\
\text { Play court }\end{array}$ & 183,693 & 153,584 & 16,979 & 154,533 & 90,611 & 182,153 \\
\hline Parcourse & 102,504 & 92,754 & 9,688 & 92,759 & 52,450 & 102,503 \\
\hline Plaza & 58,613 & 12,555 & - & - & 28,544 & 58,613 \\
\hline Walkway & 256,086 & 67,667 & 142,246 & - & 120,406 & 243,532 \\
\hline Parking area & 110,217 & - & - & - & 55,108 & 110,218 \\
\hline Lighting & 110,531 & - & 110,452 & - & 55,344 & 110,530 \\
\hline $\begin{array}{l}\text { Man-Made } \\
\text { Lake }\end{array}$ & 280,792 & - & - & - & $5,159,262$ & 280,792 \\
\hline Total & $8,330,614$ & 342,453 & 310,185 & 265,736 & $5,690,809$ & $8,390,805$ \\
\hline Overall Built & $8,330,614$ & $6,164,154$ & 310,185 & 265,736 & $5,690,809$ & $8,390,805$ \\
\hline $\begin{array}{l}\text { Feature } \\
\text { Carbon } \\
\text { Emission, } \\
\mathrm{kgCO}_{2} \mathrm{eq}\end{array}$ & \multicolumn{6}{|c|}{$29,152,303$} \\
\hline
\end{tabular}

construction stage. The machinery involved were the Front-End Loader (25 tonnes) (i.e. for lake excavation and backfilling), Loader (i.e. for loading bulk earthworks into the truck), and Dump Truck (i.e. for moving bulk earthworks to other sites within the construction site).

\section{Planting Inventory}

$\mathrm{CO}_{2}$ emission for planting installation stage is also a one-time emission. Emission during the planting maintenance stage was estimated from the tree pruning, fertilizing and plant matter clearance and multiplied with park age. Planting renewal emission consisted of three substages, namely replanting, planting addition, and transplanting. The $\mathrm{CO}_{2}$ emission of replanting works derived from the substituting sick or dead trees with similar species. The 
emission for planting addition works, including adding more quantities of trees of similar or different species. The emissions were derived from transplanting works, including the transplanting existing trees at renovated, expanded or reconstructed areas to other location within the urban park.

A total of 1348 trees (TBKJ) and 551 trees (TAPJ) were found along the study transects. A sum of 9,397,508 $\mathrm{kgCO}_{2}$ eq (Table 8) and 1,868,777 $\mathrm{kgCO}_{2}$ eq (Table 9) of $\mathrm{CO}_{2}$ emissions of planting works was produced during the construction, maintenance and renewal stages of the TBKJ and TAPJ, respectively. Planting work $\mathrm{CO}_{2}$ estimation was dependent on the tree numbers and turf surface areas. Project supervisors of Petaling Jaya City Council suggested that the related works to planting a tree involved planting pit preparation, tree

Table 8

Planting inventories and $\mathrm{CO}_{2}$ emission estimation for TBKJ during construction, maintenance and renewal stages

\begin{tabular}{|c|c|c|c|c|c|}
\hline \multicolumn{6}{|c|}{ Carbon Emission for Planting Works at TBKJ } \\
\hline \multirow[b]{2}{*}{ Planting Work } & \multirow{2}{*}{$\begin{array}{l}\text { Planting } \\
\text { Installation } \\
\text { Stage }\end{array}$} & \multirow{2}{*}{$\begin{array}{l}\text { Planting } \\
\text { Maintenance } \\
\text { Stage ( } 24 \text { years })\end{array}$} & \multicolumn{3}{|c|}{ Renewal Stage } \\
\hline & & & $\begin{array}{l}\text { Replanting } \\
\text { Stage }\end{array}$ & $\begin{array}{l}\text { Planting } \\
\text { addition Stage }\end{array}$ & $\begin{array}{l}\text { Transplanting } \\
\text { Stage }\end{array}$ \\
\hline Overall works & 24,631 & 39,591 & 2,058 & 12,316 & 2,058 \\
\hline Tree & 629,893 & 39,591 & 63,083 & 314,947 & 63,083 \\
\hline Turf & 159,349 & 256,127 & - & 79,674 & - \\
\hline Total & 813,873 & 335,309 & 65,141 & 406,937 & 65,141 \\
\hline \multirow{2}{*}{$\begin{array}{l}\text { Overall Planting Work } \\
\text { Carbon Emission, } \\
\mathrm{kgCO}_{2} \mathrm{eq}\end{array}$} & 813,873 & $8,047,416$ & 65,141 & 406,937 & 65,141 \\
\hline & \multicolumn{5}{|c|}{$9,397,508$} \\
\hline
\end{tabular}

* $\mathrm{CO}_{2}$ emission estimations were done using eToolLCD Software at www.etoollcd.com

Table 9

Planting inventories and $\mathrm{CO}_{2}$ emission estimation for TAPJ during construction, maintenance and renewal stages

\begin{tabular}{|c|c|c|c|c|c|}
\hline \multicolumn{6}{|c|}{ Carbon Emission for Planting Works at TAPJ } \\
\hline \multirow[b]{2}{*}{ Planting Work } & \multirow{2}{*}{$\begin{array}{l}\text { Planting } \\
\text { Installation } \\
\text { Stage }\end{array}$} & \multirow{2}{*}{$\begin{array}{l}\text { Planting } \\
\text { Maintenance } \\
\text { Stage (18 years) }\end{array}$} & \multicolumn{3}{|c|}{ Renewal Stage } \\
\hline & & & $\begin{array}{l}\text { Replanting } \\
\text { Stage }\end{array}$ & $\begin{array}{l}\text { Planting } \\
\text { addition Stage }\end{array}$ & $\begin{array}{l}\text { Transplanting } \\
\text { Stage }\end{array}$ \\
\hline Overall works & 7,148 & 11,489 & 848 & 3,574 & 845 \\
\hline Tree & 257,471 & 11,489 & 25,701 & 128,970 & 25,701 \\
\hline Turf & 33,021 & 53,076 & - & 16,511 & - \\
\hline Total & 297,640 & 76,055 & 26,548 & 149,054 & 26,545 \\
\hline \multirow{2}{*}{$\begin{array}{l}\text { Overall Planting } \\
\text { Work Carbon } \\
\text { Emission, } \mathrm{kgCO}_{2} \mathrm{eq}\end{array}$} & 297,640 & $1,368,990$ & 26,548 & 149,054 & 26,545 \\
\hline & \multicolumn{5}{|c|}{$1,868,777$} \\
\hline
\end{tabular}

* $\mathrm{CO}_{2}$ emission estimations were done using eToolLCD Software at www.etoollcd.com 
lifting, topsoil backfilling, staking erection, mulching and watering. These works required labour as site supervisor and operating the small electrical equipment. Such works indirectly caused $\mathrm{CO}_{2}$ liberation. Similarly, turf installation $\mathrm{CO}_{2}$ emissions were acquired from site supervision during soil compacting, turf laying on-site, and watering.

The total $\mathrm{CO}_{2}$ sequestration produced at TBKJ and TAPJ were 41,371,400 $\mathrm{kgCO}_{2} \mathrm{eq}$ and $9,992,415 \mathrm{kgCO}_{2} \mathrm{eq}$, respectively (Table 10). According to the maturity of vegetation, TAPJ had more matured vegetation despite its 18 years of park age compared to TBKJ (i.e. 24 years). Even though TBKJ was 24 years in age, the DBH and tree height were less matured compared to TAPJ.

Subsequent years of urban park completion require the parks to go through a series of maintenance and renewal stages throughout their management life cycle. These management activities are to ensure the parks are relevant to be used by visitors. Meanwhile, accumulated $\mathrm{CO}_{2}$ emissions throughout the service life of an urban park commencing from construction, maintenance and renewal stages are justified in Table 11. The urban park itself is a carbon sink; conversely, the urban park management procedures implemented served as the carbon source.

The findings suggested that the net carbon footprint of the urban parks during the construction, maintenance, and renewal stages over 24 years (TBKJ) and 18 years (TAPJ) was not compensated for the $\mathrm{CO}_{2}$ sequestration by its vegetation. TBKJ $(146,094,652$

Table 10

Planting inventory and $\mathrm{CO}_{2}$ sequestration estimation for TBKJ and TAPJ according to age of the parks

\begin{tabular}{|c|c|c|c|c|}
\hline \multirow[b]{3}{*}{ Planting Inventory } & \multicolumn{2}{|c|}{ Taman Bandaran Kelana Jaya (TBKJ) } & \multicolumn{2}{|c|}{ Taman Aman Petaling Jaya (TAPJ) } \\
\hline & \multicolumn{4}{|c|}{ Allometric Equation } \\
\hline & Numbers, Nos & $\begin{array}{l}\mathrm{CO}_{2} \text { Sequestration } \\
\text { Estimation, } \mathrm{kgCO}_{2} \mathrm{eq}\end{array}$ & Numbers, Nos & $\begin{array}{l}\mathrm{CO}_{2} \text { Sequestration } \\
\text { Estimation, } \\
\mathrm{kgCO}_{2} \mathrm{eq}\end{array}$ \\
\hline Trees & 1,348 & $3,272,628$ & 551 & $4,121,649$ \\
\hline \multirow[t]{2}{*}{$\begin{array}{l}\text { U.P Age }=24 \text { y and } 18 \\
\text { y }(1.40 \% \text { tree mortality } \\
\text { rate })\end{array}$} & 1,330 & $3,226,811$ & 544 & $4,063,946$ \\
\hline & Floor area, $\mathrm{m}^{2}$ & $\begin{array}{l}\text { Carbon Sequestration } \\
\text { Estimation, } \mathrm{kgCO}_{2} \mathrm{eq}\end{array}$ & Floor area, $\mathrm{m}^{2}$ & $\begin{array}{l}\text { Carbon } \\
\text { Sequestration } \\
\text { Estimation, } \\
\mathrm{kgCO}_{2} \mathrm{eq}\end{array}$ \\
\hline Turf / year & 242,368 & 212,481 & 50,225 & 44,032 \\
\hline $\begin{array}{l}24 \mathrm{y} \text { and } 18 \mathrm{y}(0.44 \% \\
\text { grass mortality rate })\end{array}$ & & $38,144,589$ & & $5,928,469$ \\
\hline $\begin{array}{l}\text { Total Softscape } \mathrm{CO}_{2} \\
\text { Sequestration, } \mathrm{kgCO}_{2} \mathrm{eq}\end{array}$ & & $41,371,400$ & & $9,992,415$ \\
\hline
\end{tabular}

* $\mathrm{CO}_{2}$ sequestration estimations were calculated using adaptation allometric equation developed by Othman and Kasim, (2016). 
$\mathrm{kgCO}_{2}$ eq) reported a higher $\mathrm{CO}_{2}$ emission by $90.7 \%$ than TAPJ $\left(14,864,511 \mathrm{kgCO}_{2}\right.$ eq $)$ due to its regular renewal compared to TAPJ (Table 12). TBKJ is a prominent spot for outdoor recreation among urban residents as the park offers a variety of park facilities. Whereby heavy usage of its facilities contributes to frequent wearing down of the built features and facilities, subsequently causing maintenance and repairing activities to be conducted. Damaged facilities trigger intense renewal works, which indicate that more $\mathrm{CO}_{2}$ emission is generated indirectly and derived from material transportation, machinery, and labour. Plantings such as trees, shrubs, and turfs are manicured regularly to ensure visitors' safety and avoiding pest inhabitation within the urban parks. Besides, user visitation frequency contributes to waste accumulation as well, hence requiring maintenance works to meet the cleanliness standard accepted by the users. Although TBKJ was six years older than TAPJ, its vegetation dissipated $\mathrm{CO}_{2}$ further due to the maintenance cycle as frequent as once every three weeks. Table 12 shows the amount of $\mathrm{CO}_{2}$ sequestered by the established vegetation, which was stochastically below $28.7 \%$ out of the total of $\mathrm{CO}_{2}$ emission produced since its previous construction stage. This study presented facts contrary to the general opinion of landscape architects and researchers who claimed urban parks to be a carbon sink medium.

The amount of carbon footprint per square metre of the urban parks is approximately $404.5 \mathrm{kgCO}_{2} \mathrm{eq} / \mathrm{m}^{2}$ for TBKJ and $185.0 \mathrm{kgCO}{ }_{2} \mathrm{eq} / \mathrm{m}^{2}$ for TAPJ. Therefore, the amount

Table 11

Total urban park carbon emission of TBKJ and TAPJ to date

\begin{tabular}{lcc}
\hline \multicolumn{1}{c}{$\begin{array}{c}\mathrm{CO}_{2} \text { Emission for every Park } \\
\text { Management Phase }\end{array}$} & $\begin{array}{c}\text { Taman Bandaran Kelana Jaya } \\
(\mathrm{TBKJ}), \mathrm{kgCO}^{2} \mathrm{eq}\end{array}$ & $\begin{array}{c}\text { Taman Aman Petaling Jaya } \\
\text { (TAPJ), kgCO } \mathrm{eq}\end{array}$ \\
\hline Construction Phase & $39,664,063$ & $8,628,254$ \\
Maintenance Phase & $18,504,792$ & $1,368,990$ \\
Renewal Phase & $46,554,397$ & $14,859,682$ \\
\hline Total Urban Park $\mathrm{CO}_{2}$ Emission to & $104,723,252$ & $24,856,926$ \\
Date, $\mathrm{kgCO}_{2}$ eq & & \\
\hline
\end{tabular}

Table 12

Net urban park carbon footprint of TBKJ and TAPJ up to date

\begin{tabular}{lcccc}
\hline $\begin{array}{c}\text { Urban Park Carbon } \\
\text { Footprint }\end{array}$ & $\begin{array}{c}\text { Taman Bandaran Kelana } \\
\text { Jaya (TBKJ), } \mathrm{kgCO}_{2} \mathrm{eq}\end{array}$ & $\begin{array}{c}\text { Percentage, } \\
\%\end{array}$ & $\begin{array}{c}\text { Taman Aman Petaling } \\
\text { Jaya (TAPJ), } \mathrm{kgCO}_{2} \text { eq }\end{array}$ & Percentage, \% \\
\hline $\begin{array}{l}\text { Total Urban Park } \\
\mathrm{CO}_{2} \text { Emission }\end{array}$ & $104,723,252$ & $71.7 \%$ & $24,856,926$ & $71.3 \%$ \\
$\begin{array}{l}\text { Total Urban Park } \\
\mathrm{CO}_{2} \text { Sequestration }\end{array}$ & $41,371,400$ & $28.3 \%$ & $9,992,415$ & $28.7 \%$ \\
$\begin{array}{l}\text { Net Carbon } \\
\text { Footprint up to } \\
\text { Date, } \mathrm{kgCO}_{2} \text { eq }\end{array}$ & $146,094,652$ & & & \\
\hline
\end{tabular}

$*$ Net Carbon footprint $=$ Total Urban Park $\mathrm{CO}_{2}$ Emission - Total Urban Park $\mathrm{CO}_{2}$ Sequestration 
of tree emission was consistent as $467.3 \mathrm{kgCO} 2 \mathrm{eq} / \mathrm{m}^{2}$ because of the works involved were similar such as tree pit preparation, machinery for tree lifting, and labour top-soil backfilling. In contrast, the amount of turf emission was consistent as $0.78 \mathrm{kgCO} 2 \mathrm{eq} / \mathrm{m}^{2}$ due to works involved in handling turf, namely labour for turf laying, top-soil backfilling and compacting, and watering.

The amount of tree sequestration was irregular at $2427 \mathrm{kgCO}_{2} \mathrm{eq} / \mathrm{tree}$ (TBKJ), and 7480 $\mathrm{kgCO}_{2}$ eq/tree (TAPJ) due to the different soil type, mostly since TBKJ was previously an ex-mining site, thus causing the vegetation's slow growth to be influenced by the nutrientdeficient soil. In contrast, TAPJ vegetation consisted of species such as Syzygium grande $\left(0.65 \mathrm{gcm}^{-3}\right)$, Lagerstroemia speciose $\left(0.83 \mathrm{gcm}^{-3}\right)$, and Ficus roxburghii $\left(0.52 \mathrm{gcm}^{-3}\right)$, which was fast-growing, suitable to local climate, and had a higher wood density. TBKJ consisted of species such as Albizia saman $\left(0.46 \mathrm{gcm}^{-3}\right)$, Cocos nucifera $\left(0.58 \mathrm{gcm}^{-3}\right)$, and Acacia auriculiformis $\left(0.75 \mathrm{gcm}^{-3}\right)$, which had a lower wood density. Besides, TAPJ locales were at the valleys where water collection occurred, whereby the high level of moisture in its soil supported rigorous tree growth. TBKJ had low sequestration rates as the park had a higher mortality rate caused by a natural disaster such as strong winds and floods. These events were depriving trees by damaging tree branches and water ponding at root areas.

\section{CONCLUSION}

This study concluded that urban park management procedures contributed to the release of $\mathrm{CO}_{2}$ emission by $71.3 \%-71.7 \%$ derived from the construction, maintenance, and renewal stages. Carbon storage by urban vegetation was only $28.3 \%-28.7 \%$ for as long as 18 to 24 years of age parks. The studied urban parks serve as the carbon source instead of a carbon sink medium in the context of the urban location. This study discovered that built features and planting works of an urban park emitted additional carbon content than that being absorbed. The aggravated stage of carbon emitted can be mitigated by reducing the maintenance and renewal frequencies conducted in an urban park.

This study suggests several ways to reduce the carbon footprint of urban parks. First, retrofitting the existing light bulb to a more energy-efficient bulb and reduce its operating hours. Second, reducing earthwork excavation to alter landforms, instead of blend and adapt the proposed design with the existing site. It is encouraging to use eco-friendly or recyclable materials for constructing the built feature so that is can reduce resource wastage. Finally, reducing planting maintenance frequencies by focusing on the areas where people used the most. The $\mathrm{CO}_{2}$ emission allowance was based on the amount of vegetation able to sequester yearly. It is advisable to identify the amount of $\mathrm{CO}_{2}$ sequestration by greenery at the parks and use the sequestration value as carbon emission allowance to conduct management activities. 


\section{ACKNOWLEDGEMENT}

The authors would like to acknowledge Majlis Bandaraya Petaling Jaya and Khoo Soon Lee Realty Sdn Bhd for support and data supplication of the studied urban parks.

\section{REFERENCES}

Aleixo, I., Norris, D., Hemerik, L., Barbosa, A., Prata, E., Costa, F., \& Poorter, L. (2019). Amazonian rainforest tree mortality driven by climate and functional traits. Nature Climate Change, 9(5), 384-388. doi: https:// doi.org/10.1038/s41558-019-0458-0

Alig, R. J., Kline, J. D., \& Lichtenstein, M. (2004). Urbanization on the US landscape: looking ahead in the 21st century. Landscape and Urban Planning, 69(2-3), 219-234. doi: https://doi.org/10.1016/j. landurbplan.2003.07.004

Almeida, C. M. V. B., Mariano, M. V, Agostinho, F., Liu, G. Y., \& Giannetti, B. F. (2018). Exploring the potential of urban park size for the provision of ecosystem services to urban centres : A case study in São Paulo, Brazil. Building and Environment, 144(August), 450-458. doi: https://doi.org/10.1016/j. buildenv.2018.08.036

Arbor Day Foundation. (2020). The basic spacing guide from various distances and various tree heights. Retrieved March 3, 2020, from https://www.arborday.org/trees/rightTreeAndPlace/size.cfm

Arellano, G., Medina, N. G., Tan, S., Mohamad, M., \& Davies, S. J. (2019). Crown damage and the mortality of tropical trees. New Phytologist, 221(1), 169-179. doi: https://doi.org/10.1111/nph.15381

Begum, R. A. (2017). Tackling climate change and Malaysia's emission reduction target. Retrieved March 3, 2020, from http://magazine.scientificmalaysian.com/issue-13-2017/tackling-climate-change-malaysiasemission-reduction-target/

Braun, R. C., \& Bremer, D. J. (2019). Carbon sequestration in Zoysiagrass Turf under different irrigation and fertilization management regimes. Agrosystems, Geosciences and Environment, 2(1), 1-8. doi: https:// doi.org/10.2134/age2018.12.0060

Chen, W. Y. (2015). The role of urban green infrastructure in offsetting carbon emissions in 35 major Chinese cities: A nationwide estimate. Cities, 44, 112-120. doi: https://doi.org/10.1016/j.cities.2015.01.005

Connor, K. O., Pocock, C., Barthelmeh, M., \& Davis, S. (2011). Carbon and environmental profiling of hard landscape materials landscape materials (Research Report). Lincoln University, New Zealand: Centre for Land Environment \& People.

De Wolf, C., Pomponi, F., \& Moncaster, A. (2017). Measuring embodied carbon dioxide equivalent of buildings: A review and critique of current industry practice. Energy and Buildings, 140, 68-80. doi: https://doi. org/10.1016/j.enbuild.2017.01.075

Eslamirad, N., \& Mahdavinejad, M. (2018, September 26-28). External shadings effect on operating energy based on lcea, case study: A residential building in Tehran. In 2018 Building Performance Analysis Conference and SimBuild (pp. 494-501). Chicago, Illinois. 
Feltynowski, M., Kronenberg, J., Bergier, T., Kabisch, N., Łaszkiewicz, E., \& Strohbach, M. (2017). Challenges of urban green space management in the face of using inadequate data. Urban Forestry and Urban Greening, 31, 56-66. doi: https://doi.org/10.1016/j.ufug.2017.12.003

Haq, S. M. A. (2011). Urban green spaces and an integrative approach to sustainable environment. Journal of Environmental Protection, 02(05), 601-608. doi: 10.4236/jep.2011.25069

Hisham, F. D. B., Shahidan, M. F., \& Ja'afar, M. F. Z. (2018). Stages and elements affecting development of low carbon parks in Malaysia: An expert review. Alam Cipta, 11(1), 2-8.

Kabanov, V. (2018). Measurement of the intensity of construction and installation works taking into account the level of organizational and technological reliability. In MATEC Web of Conferences (Vol. 193, pp. 1-8). Les Ulis, France: EDP Sciences. doi: https://doi.org/10.1051/matecconf/201819305056

King, D. A., Davies, S. J., \& Noor, N. S. M. (2006). Growth and mortality are related to adult tree size in a Malaysian mixed dipterocarp forest. Forest Ecology and Management, 223(1-3), 152-158. doi: https:// doi.org/10.1016/j.foreco.2005.10.066

Lauenroth, W. K., \& Adler, P. B. (2008). Demography of perennial grassland plants: Survival, life expectancy and life span. Journal of Ecology, 96(5), 1023-1032. doi: https://doi.org/10.1111/j.1365-2745.2008.01415.x

Marcum, K. (2010). Tropical turfgrass mowing. Retrieved March 3, 2020, from https://www.nparks.gov.sg/-/ media/cuge/pdf/rtn-03-2010---tropical-turfgrass-mowing.pdf?la=en\&hash=F99D23289A512EFFAFB6 1CBC69DA6C67091249C9

Ngadiman, N., Kaamin, M., Sahat, S., \& Mokhtar, M. (2018). Production of orthophoto map using UAV photogrammetry: A case study in UTHM Pagoh campus. In AIP Conference Proceedings 2016 (Vol. 020112, pp. 1-6). Melville, USA: AIP Publishing LLC. doi: https://doi.org/10.1063/1.5055514

Othman, R., \& Kasim, S. Z. A. (2016). Assessment of plant materials carbon sequestration rate for horizontal and vertical landscape design. International Journal of Environmental Science and Development, 7(6), 410-414. doi: 10.7763/IJESD.2016.V7.810

Pocock, C. (2009). The carbon landscape: Managing the carbon impact in landscape design. Pocock Design Environment. Retrieved March 3, 2020, from http://www.carbonlandscape.com/the-carbonlandscape-2007.html

Shashi, M., \& Jain, K. (2007). Use of photogrammetry in 3D modeling and visualization of buildings. Journal of Engineering and Applied Sciences, 2(2), 37-40.

Strohbach, M. W., Arnold, E., \& Haase, D. (2012). The carbon footprint of urban green space-A life cycle approach. Landscape and Urban Planning, 104(2), 220-229. doi: https://doi.org/10.1016/j. landurbplan.2011.10.013

Sun, R., \& Chen, L. (2017). Effects of green space dynamics on urban heat islands: Mitigation and diversification. Ecosystem Services, 23(December 2016), 38-46. doi: https://doi.org/10.1016/j.ecoser.2016.11.011 